\title{
ASSESSMENT OF CUSTOMER'S SATISFACTION ON BAGGAGE HANDLING SERVICE AT SOEKARNO-HATTA INTERNATIONAL AIRPORT
}

\author{
Amelia Fitantri $^{1}$, Adha Iqbal Madhani ${ }^{2}$, Sekar Widiastuti ${ }^{3}$ \\ 1. STMT Trisakti, 2. STMT Trisakti, 3. STMT Trisakti \\ $\triangle$ corresponding author: Ameliafitantri98@gmail.com
}

\begin{abstract}
The role of the airport as a meeting place between the users of air transport (passenger) and air transport provider (airlines) is very important. Passengers' satisfaction is an important part of the service at the airport. Trying to provide excellent service for baggage handling becomes one of the important factors to improve passengers' satisfaction quality. The Soekarno-Hatta International Airport satisfaction index is still not satisfactory especially on manual baggage handlers. Researchers tried to find out whether the perception of passengers about the quality of service related to the satisfaction of Soekarno-Hatta Airport. This research uses quantitative descriptive method. Data were collected from the questionnaire.

Keywords: baggage handling system; performance service; costumer satisfaction; service quality; airport
\end{abstract}

\section{Introduction}

As many people are using air transport services, it is now become one of the efforts of airlines to increase its fleet of aircraft. This became one of the efforts of the company to improve its performance (Indra Yuzal, 2016). In addition, airlines are also competing to improve their performance, such as providing the best service to service users and discipline work (Sembiring, Honny Fiva Akira, 2016). Extremely important services are given to give a positive impression to the customer, with the best service will certainly have an impact on customer satisfaction.(Vidyana Mandrawaty, 2016.)

Airports according to the transportation department shall be land and / or water areas with certain limits used as an aircraft's landing and take-off aircraft, passengers, loading and unloading, and intra- and intermodal transport sites equipped with safety facilities and aviation security, as well as basic facilities and other supporting facilities. ("Pengertian Bandar Udara," 2013) Problems that often occur in baggage handling - baggage 
carrying passengers do not escape from various problems. Cases related to baggage handling still use manual processes that eventually take a long time. Therefore, it requires a system that can meet the needs of fast service based on computerization. In the airline industry passenger satisfaction is an important thing that must be considered by the airlines. Passenger satisfaction is one of the factors causing a passenger to become a company customer in the airline concerned (Saribanon, Euis, Rohana Sitanggang, 2016). If perceived service is perceived as expected, service quality is perceived as good and satisfactory, so that it will increase the level of consumer loyalty. Conversely, if the service received is lower than expected, the quality of service is perceived poorly that will impact the lower level of consumer loyalty (Saribanon, Euis, Rohana Sitanggang, 2016).

Satisfaction is generally interpreted as a feeling of pleasure or disappointment of a person as a result of the comparison between services provided with the desired expectations. Based on the understanding above, it can be concluded that basically the sense of satisfaction includes the difference between the level of importance and performance or perceived results. When Arrival Hall officers provide baggage service to passengers with more than passenger expectations, passengers will feel very satisfied, and vice versa. So the level of satisfaction can be measured through whether or not the performance provided by the officer Arrival Hall with expectations desired by passengers.

The key to keeping the company in existence is the company's ability to retain its customers. When customers leave, the existence of a company is no longer needed even vice versa. Therefore, the company needs to detect the attitude of its customers (Muhammad Resky, 2014). According to Parasuraman, et. al (1998a), the attitude of a consumer to the company is often formed from direct consumer contact with the object of attitude. 


\section{Method}

The object of this study consists of passenger satisfaction experience. This suggestion is especially at Soekarno Hatta International Airport This study is descriptive quantitative. Regarding the facts, nature and relationships studied. The data collected were analyzed, and made conclusions to answer the existing problems. Cartesius diagram analysis was a tool for this paper. Data from questionnaires with gender of the 153 respondents, who had been a passenger at Soekarno-Hatta international airport i.e. $49 \%$ female ( 75 people), and $51 \%$ (78 people) male sex. While data collection techniques mention quantitative research was a research that demands the use of numbers, ranging from data collection, interpretation of data, and appearance of results.

Sugiyono (2015) explained that quantitative methods were used when:

1. If the problem that was the starting point of research is clear. Problem is a deviation between what should be and what happens, between rules and execution, between theory and practice, between plans and implementation.

2. When the researcher wants to get broad information from a population. Quantitative research methods are suitable to be used to obtain broad but not in-depth information. If you want to know the effect of certain treatment / treatment against others. For this purpose the most suitable experimental method was used. From the data collected in this study it had been found that passenger baggage acceptance satisfaction often occurs in the form of damage or loss due to an insignificant process that affected the process performance time and may be delayed and very inefficient. This was also due to human resources (porter) in handling the baggage process, we need to conduct supervsion to the porter (Andri, Roswan Kasim, 2016).

\section{Discussion and Result}

Article 1 (14) of the Civil Aviation Act of 2009 provides that air transport is an activity that uses aircraft to transport passengers, cargo and / 
or mail for one or more routes from one airport to another airport or several airports. Inconnection with the service. Air transport consists of full service, medium service and no-frills service (Saribanon, Euis, Rohana Sitanggang, 2016).

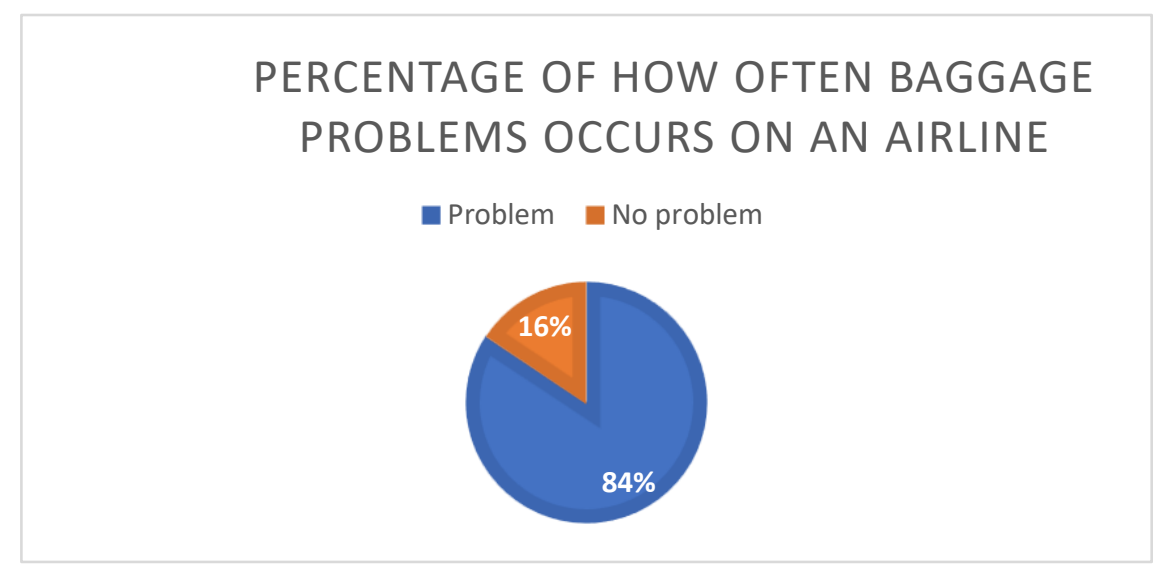

Figure 1. Profile of Respondents Questionnaire

Data collection in this study was done by distributing questionnaires distributed to the respondents, then the questionnaire that has been disseminated will be developed to researchers.

\section{Research Result Discussion}

This research is aimed to analyze the passenger relationship with the officer's performance in baggage service with passenger satisfaction level at Soekarno-Hatta International Airport. Problematic research data as much as 84\% (129 people) of 153 respondents deployed. And the impact on Passenger Satisfaction for the aviation industry. Passenger satisfaction is an important thing that must be considered by the airline.

Passenger satisfaction is one of the factors causing a passenger to become a company customer of a certain airline. Therefore, the level of satisfaction can be measured through whether or not the performance provided by the officer in accordance with the passenger's desired expectation. Performance of officers who experience delays and problems in handling that sometimes have problems and not according to existing rules. (REZA VIRGIAWAN T., 2013) 
Table 1. Customer Satisfaction Table

\begin{tabular}{|c|c|}
\hline Description & Persentase \\
\hline Very Satisfaction & $8,6 \%$ \\
\hline Satisfaction & $9,9 \%$ \\
\hline Bad & $51 \%$ \\
\hline Very Bad & $30,5 \%$ \\
\hline
\end{tabular}

The measurement of the service quality at Soekarno-Hatta International Airport that relates to the quality of service perceived by consumers on the dimensions of Tangibles, Reliability, Responsiveness, Assurance and Emphaty, the variables include (Kartikasari, 2013):

1. The Independent Variable (independent variable) is the service quality dimension consisting of Tangibles, Reliability, Reponsiveness, Assurance, Emphaty.

2. Dependent Variable (dependent variable) is satisfaction felt by Consumer. Operational definitions and indicators used to measure independent variables based on service quality dimensions include (Andri, Roswan Kasim, 2016):

a) Tangibles (physical evidence), for instance, the physical appearance of the company such as facilities, personnel appearance, and communication materials. Each airport has its own way to invite employees at the Airport to always look clean and neat, the statement / directions service at the airport interesting views.

b) Reliability (reliability), namely the ability of the company to provide services in accordance with the promised accurately and reliably. In measuring these variables, the indicator used is: every customer who has problems at the airport employees is really trying to be helped, the service at the airport is given correctly from the beginning, the service at the airport delivered in accordance with the time promised, the ease of getting information at the airport.

c) Responsiveness (responsiveness), which is a willingness to help and provide fast and precise service. The indicators used to 
measure these variables are: Certainty of service delivery time is clearly informed to the consumer, the customer is served promptly / quickly by airport employees, airport employees are always willing to assist the customers, the employees at the airport are not too busy to respond quickly to the demand / needs consumer.

d) Assurance (assurance and confidence), namely knowledge, courtesy, and the ability of airline employees to cultivate the trust of consumers / passengers to the airlines. To measure this variable the indicators used are: Airport employees are trustworthy, consumers feel safe to interact at airports, Airport employees are always polite to consumers, Airport employees are knowledgeable to answer consumer questions.

e) Empathy (Concern), the level of care and attention given by the service provider to the consumers / passengers who will depart and who come. Indicators used by this variable are: Airport operational hours are suitable / convenient for consumers, Airport employees give personal attention to consumers, airport management / employees prioritize the interests of consumers, Airport employees understand the specific needs of consumers. While the operational definition and the indicators used to measure the dependent variable based on customer satisfaction are as follows: Consumer / passenger satisfaction is the result of a thorough evaluation of the conformity between the expectation of obtaining services that should be received from SoekarnoHatta International Airport. 


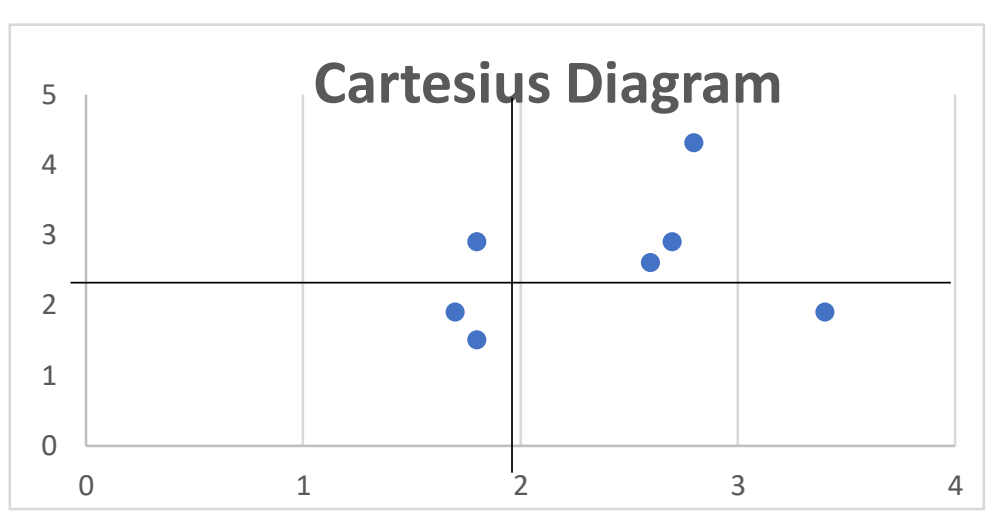

Figure 2. Cartesius Diagram

Based on Cartesian diagram in Figure above can be seen the position of each variable contained in quadrants I, II, III, and IV.

1. Quadrant I

Quadrant I shows variables that are considered to affect customer satisfaction, including service elements that are considered very important, and the airport has maximized its performance in accordance with the rules and procedures. The variables included in quadrant I are service with comfort for passengers.

2. Quadrant II

Quadrant II shows the element of service that show many problems by the airline officer. Therefore, the variables that enter in this quadrant must always be maintained by the airline officer because it is considered very important and very satisfying to nillai the interests of passengers. The variables included in quadrant II are how to handle baggage issues to destinations, trusts to airlines, and airline valuations that are critical to the value of airlines in the future.

3. Quadrant III

Quadrant III shows several important factors to prove the handling of baggage handling problems to passengers and have an effect on the airline for the value of the company's image. The variables included in quadrant III are the airlines replacing the luggage quickly and handling in accordance with the procedure.

4. Quadrant IV 
Quadrant IV indicates the factors that affect baggage handler satisfaction that passengers contend to reduce the baggage problem why not immediately use the new Baggage Handling System as in terminal 3 despite having to pay attention to other things. And Human Resources that must be analyzed because it has an important effect in handling baggage problems manually. The application of automated baggage handling system automatically makes the carrier service system (porter) at Soekarno-Hatta Airport removed. The automatic trunk system is expected to prevent it from "baggage trucks" such as those affecting passengers on Airline X, whose case is being handled by the Soekarno - Hatta Airport Police. In other words, the variables included in this quadrant are considered less important but are the reference for companies managing them when looking at other things. The variables included in quadrant IV are services in accordance with procedures not violating established rules and passengers' desire to reduce any problems on passenger baggage.

\section{Conclusion}

Based on the research results obtained, to maintain their integrity to increase consumer confidence in producing poor service becomes better and more reliable. This study aims to determine the effect of service quality on customer satisfaction at Soekarno-Hatta Airport, and things that become the target of search is dominant influence consumer satisfaction. The conclusions that can be drawn from problem analysis, data analysis up to the discussion that has been stated in the previous, can be drawn conclusion that is:

In fact the Airport Service Operations Unit is at the forefront of airport operations, however, it has not been matched by reliable personnel and adequate facilities. In terms of human resources, in addition to the pattern system that helps especially activities addition training (training) to be ready 
and better understand, sometimes, there are also officers "origin so" placed (Sandriana Marina, 2016).

Satisfaction can be improved if we can identify the factors that influence the improvement of consumer satisfaction and analyze the lack of service to maximize the quality of service. Analyzing these factors aims to determine how much influence on customer satisfaction. In this case the quality of service at Soekarno-Hatta Airport.

1. Services undertaken at Soekarno-Hatta Airport need to be `improved in order to obtain customer satisfaction that can not be separated from the quality of service provided by the airport.

2. The airport as a special training to all airport officers regarding Service Exellence in order to increase airport facilities. And the airport is good to maximize their human resources by giving priority to professionalism.

\section{References}

Andri, Roswan Kasim, E. W. (2016). Pelayanan Bandar Udara Halim Perdana Kusuma Dan Bandar Udara Husein Sastranegara.

Indra Yuzal, A. W. (2016). Pelayanan Fasilitas Terminal Bagi Pengguna Jasa Penerbangan.

Kartikasari, H. D. (2013). Analisis Kepuasan Pelanggan Dengan Metode Importance Performance Analysis Dan Penggunaan Grafik Untuk Pengendalian Kualitas Jasa (Studi Kasus Di Bri Unit Wlingi Kantor Cabang Blitar).

Muhammad Resky, J. S. (2014). Fungsi Dan Kelemahan Unit Operasi Pelayanan Di Bandara.

Pengertian Bandar Udara. (2013). Retrieved November 12, 2017, From Http://Hubud.Dephub.Go.Id/?Id/Page/Detail/44

Reza Virgiawan T. (2013). Analisis Pengaruh Kualitas Pelayanan Terhadap Kepuasan Konsumen Di Bandar Udara Internasional Sultan Hasanuddin Makassar.

Sandriana Marina, A. W. (2016). Domestic Air Transport Regulations In Indonesia.

Saribanon, Euis, Rohana Sitanggang, A. (2016). The Satisfaction Of Transportation's Customers To Enchance Loyalty.

Sembiring, Honny Fiva Akira, D. W. E. (2016). Keseimbangan Antara Disiplin Kerja Dan Kompensasi Dengan Produktivitas Kerja Karyawan Di Perusahaan Pelayaran.

Sugiyono, D. P. (2015). Metode Penelitian Pendidikan (Pendekatan Kuantitatif, Kualitatif Dan R\&D. Bandung. 
Vidyana Mandrawaty, S. S. (2016). Hubungan Antara Kinerja Petugas Arrival Hall Dalam Pelayanan Bagasi Dengan Tingkat Kepuasan Penumpang Maskapai Garuda Indonesia Di Bandara Internasional Juanda Surabaya. 